\title{
Comparison of satellite-derived with ground-based measurements of the fluctuations of the margins of Vatnajökull, Iceland, 1973-92
}

\author{
Richard S. Williams, Jr, ${ }^{1}$ Dorothy K. Hall, ${ }^{2}$ Oddur Sigurøsson, ${ }^{3}$ Janet Y. L. Chien ${ }^{4}$ \\ ${ }^{1}$ U.S. Geological Survey, Quissett Campus, Woods Hole, MA 02543, U.S.A. \\ ${ }^{2}$ NASA, Goddard Space Flight Center, Code 974, Greenbelt, MD 20771, U.S.A. \\ ${ }^{3}$ National Energy Authority, Grensásvegi 9, IS-108, Reykjavık, Iceland \\ ${ }^{4}$ General Sciences Corporation, Laurel, MD 20707, U.S.A.
}

\begin{abstract}
Vatnajökull, Iceland, is the Earth's most studied ice cap and represents a classical glaciological field site on the basis of S. Pálsson's seminal glaciological field research in the late 18 th century. Since the 19 th century, Vatnajokull has been the focus of an array of glaciological studies by scientists from many nations, including many remotesensing investigations since 1951. Landsat-derived positions of the termini of 11 outlet glaciers of Vatnajökull were compared with frontal positions of six of these 11 outlet glaciers determined by field observations during the period 1973-92. The largest changes during the 19 year period (1973-92) occurred in the large lobate, surge-type outlet glaciers along the southwestern, western, and northern margins of Vatnajökull. Tungnaárjökull receded $-1413 \pm 112 \mathrm{~m}(-1380 \pm 1 \mathrm{~m}$ from ground observations), and Brúarjökull receded $-1975 \pm 191 \mathrm{~m}$ (-2096 $\pm 5 \mathrm{~m}$ from extrapolated ground observations) between 1973 and 1992. Satellite images can be used to delineate glacier margin changes on a time-lapse basis, if the glacier margin can be spectrally discriminated from terminal moraines and sandur deposits and if the advance/recession is larger than maximum image pixel size. "Local knowledge" of glaciers is critically important, however, in the accurate delineation of glacier margins on Landsat images.
\end{abstract}

\section{INTRODUCTION}

During the past 25 years, many remote-sensing techniques have been applied to the study of glaciers, including measurements of (1) absolute ice thickness by radio-echo sounding from surface and airborne platforms, (2) changes in surface elevation over time with aerial photogrammetric methods and by geodetic airborne or spaceborne radar and laser altimetry, (3) delineation of the surface expression of glacier facies with satellite sensors, and (4) measurements of the fluctuations of the termini of valley glaciers and outlet glaciers (and margins) from ice fields, ice caps and ice sheets (Williams and Hall, in press). Often, satellite and airborne remote-sensing studies of glacier fluctuations do not have the benefit of ground observations to confirm the measurements. In this paper, however, we analyze Landsat images acquired between 1973 and 1992, in combination with field observations made during the same interval, to compare the measurement of changes in the termini of outlet glaciers and margin of Vatnajökull, Iceland (Figs 1 and 2). Variations of Iceland's glaciers are reported annually in Jökull.

The Earth's smaller glaciers have generally been receding during the 20th century (Wood, 1988; Oerlemans, 1994). This has been accompanied by an estimated $1-3 \mathrm{~mm}^{-1}$ rise in sea level (Paterson, 1994), perhaps as much as one-third of which has been caused by reduction in glacier-ice volume primarily from southeastern Alaska (Meier, 1984). The terminus-position changes of small glaciers often occur on a decadal time-scale, because smaller glaciers react more rapidly to climate change, according to Haeberli (1995) and Haeberli and Hoelzle (1995). Termini of Icelandic glaciers react to climate on a decadal time-scale regardless of their length (Sigurðsson and Jónsson, 1995). Sustained recession of a glacier terminus is usually indicative of a negative glacier mass balance, although it is possible for a glacier to increase in volume while its front is receding (Meier, 1984). In general, however, glaciers with a negative mass balance will retreat over time, although "large and relatively flat glaciers have a tendency of downwasting rather than retreating in case of rapid warming" (personal communication from W. Haeberli, 1996; cf. Haeberli and Hoelzle, 1995).

An ice cap is a dome-shaped mass of ice, $<50000 \mathrm{~km}^{2}$ in area, that completely covers the terrain except for a few internal and marginal nunataks; it usually has one or more lobate or valley outlet glaciers. Ice caps are vulnerable to climate change, particularly those in the temperate areas of the Northern Hemisphere, because even small changes in the elevation of the equilibrium line can markedly affect the relationship of the size of the accumulation area to the ablation area. There is a marked decrease in the accumulation area in response to upward movement of the equilibrium line and a concomitant increase in the ablation area; as a result, total ice-cap area can shrink rapidly (e.g. Ok ice cap in Iceland (Williams, 1986a)), the shrinkage including recession of its outlet glaciers. 


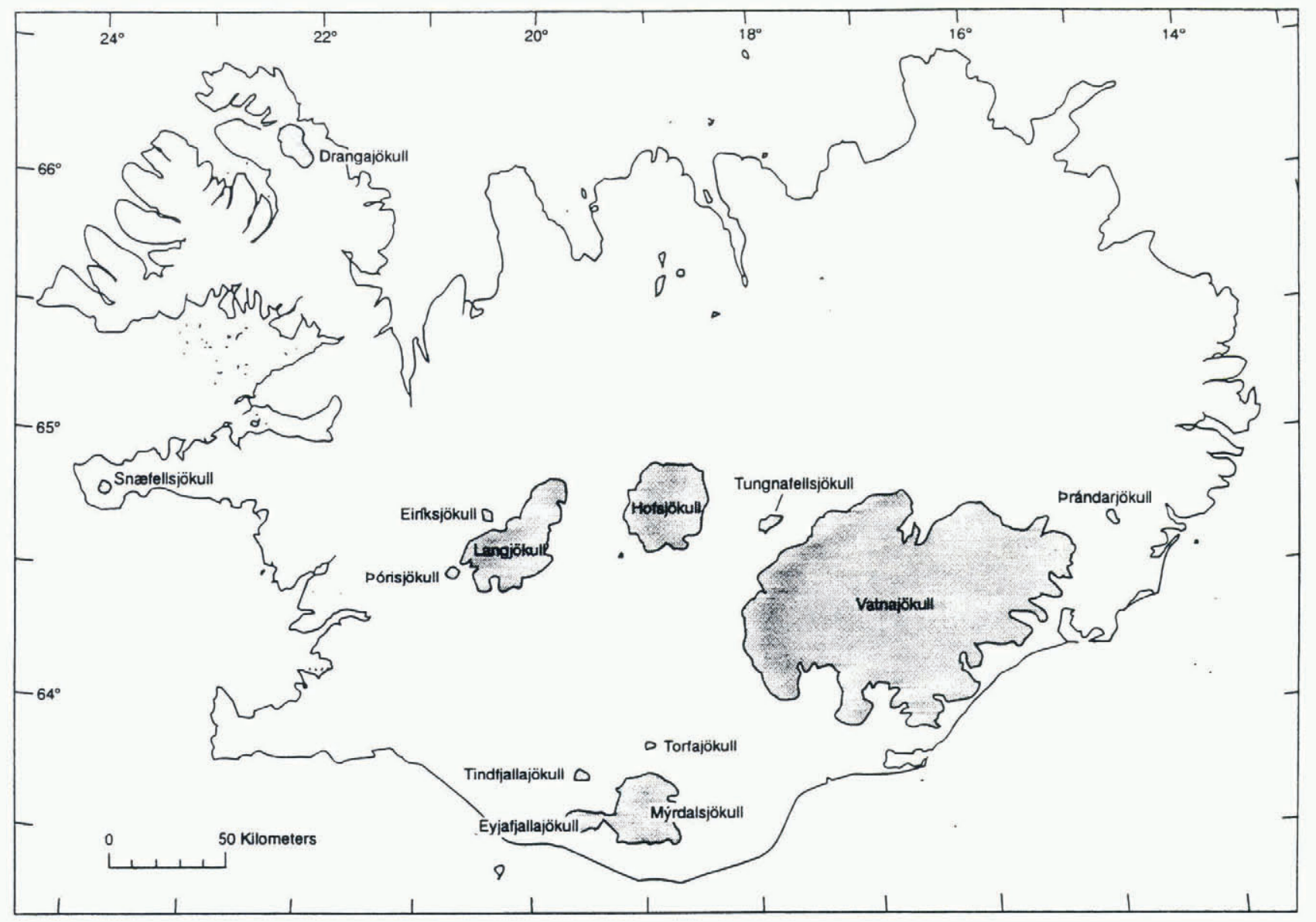

Fig. 1. Sketch map showing the 13 principal ice caps of Iceland (modified from Williams, 1983).

\section{Background}

Vatnajökull (Fig. 2), Iceland's largest glacier (Björnsson, 1980a, 1980b; Williams, 1983), is the Earth's most studied ice cap and represents a classical glaciological field site on the basis of the work in the late 18th century by the pioneer glaciologist S. Pálsson (Thórarinsson, 1960), the glaciological work in the late 19 th century/early 20 th century by Thoroddsen (1892) and pioneering glaciological research in the late 1930s and early 1940s by Ahlmann and Thórarinsson (1937-43). For the past century, Vatnajökull has been the focus of a vast array of glaciological studies by scientists from many nations, and much of the research has been published in fökull and Geografiska Annaler.

For the past 45 years, Vatnajökull, the largest $\left(8100 \mathrm{~km}^{2}\right)$ of Iceland's 13 ice caps $>10 \mathrm{~km}^{2}$ in area (Fig. 1), has been the subject of numerous remote-sensing investigations, using sensors mounted on ground, airborne and satellite platforms. A large variety of sensors have been used to (1) determine its thickness (and subglacier topography) (Björnsson, 1988), (2) measure its area (Williams, 1987), (3) delineate the surface expression of subglacier volcanoes and surface manifestations of subglacier volcanic and/or geothermal activity (Thórarinsson and others, 1974), (4) map glacier facies (Williams and others, 1991), (5) measure changes in surface elevation (Garvin and Williams, 1993), and (6) monitor and measure fluctuations of the margins of the outlet glaciers (Hall and others, 1992). For the 19 year period considered in this paper, most of its outlet glaciers measured were in recession, many as a result of post-surge downwasting.
A large ice cap such as Vatnajökull, with its 38 named and several unnamed outlet glaciers (Fig. 2), does not function as a unified mass of ice. Each of its outlet glaciers occupies its own hydrological basin (Björnsson, 1988); each responds to its unique subglacier topographic configuration and state of mass balance. In addition, many of Vatnajökull's outlet glaciers surge periodically (Thórarinsson, 1969) or are affected by jökulhlaups caused by either subglacier volcanic/geothermal activity (Björnsson, 1988) or failure of ice-dammed lakes (Thórarinsson, 1974).

\section{History of fluctuation measurements of Vatna- jökull's outlet glaciers}

In the 1930s, systematic ground observations of the annual fluctuations of some of the termini of glaciers in Iceland, including some of the outlet glaciers of Vatnajökull, were initiated by Eypórsson (1931, 1949, 1963) and Eiríksson (1932). Since the publication of the first volume of Jokull in 1951, annual compilations of glacier fluctuations in Iceland ("Jöklabreytingar") have been published by a succession of Icelandic glaciologists: J. Eypórsson (vols 1-16 (1951-66)), S. Rist (vols 17-37 (1967-87)), and O. Sigurðsson (vol. 38(1988-present)). At the present time, the frontal positions of 19 named outlet glaciers from Vatnajökull are monitored on the ground (at 23 observation stations) generally on an annual basis, by trained lay persons who belong to the Iceland Glaciological Society, other occasional observers and glaciologists. Ground-based measurements are made with a tape measure from a fixed point (e.g. cairn, steel pole) with an error of $\pm 1 \mathrm{~m}$; in extreme cases, where it is difficult 


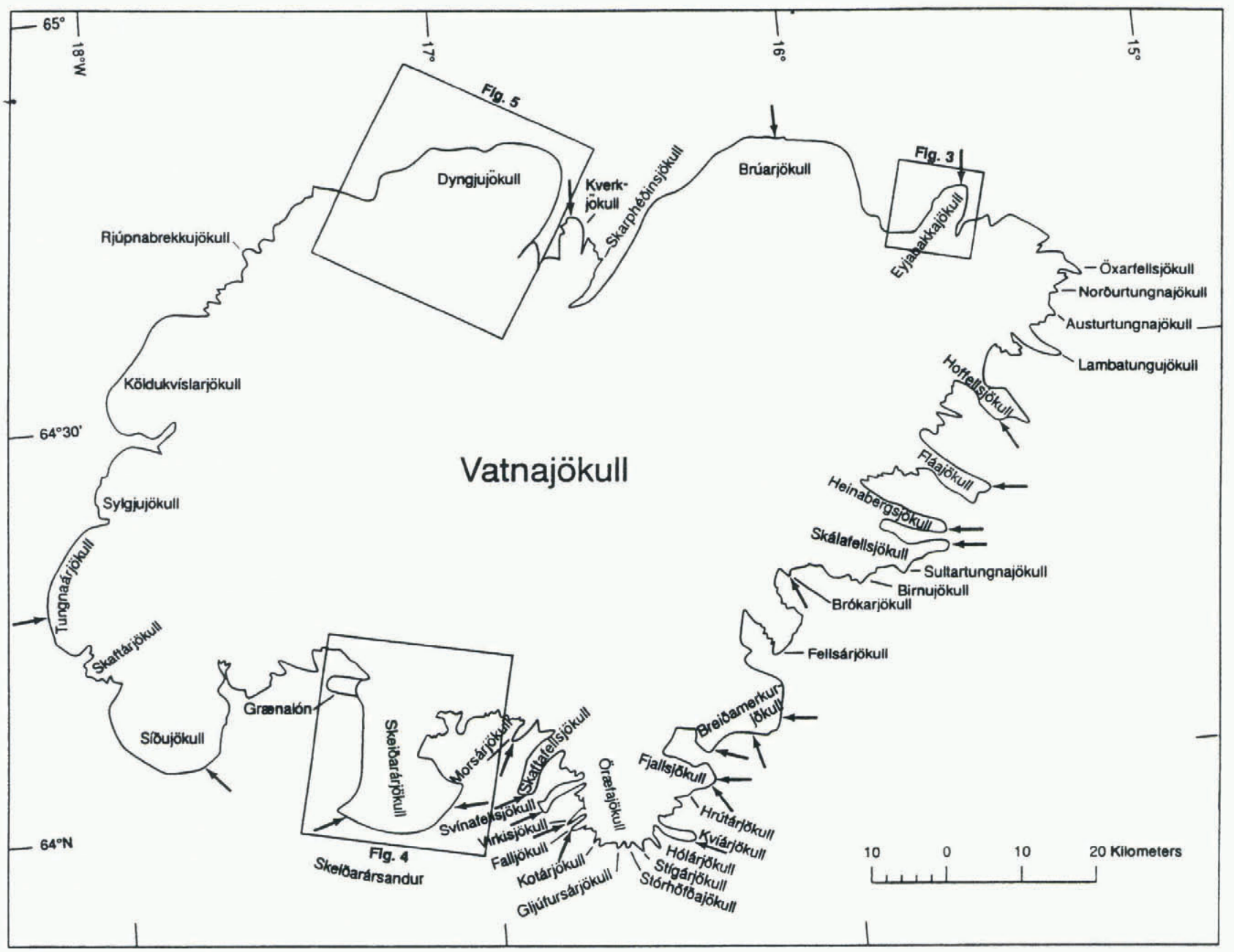

Fig. 2. Map of Vatnajökull, showing the 38 named outlet glaciers and one interior ice cap (Örefajökull). The margin of Vatnajökull is delineated from the 22 September 1973 Landsat MSS image (1426-12070; from Williams, 1987). Arrows point to 23 locations where ground observations are made on a regular basis (usually annually) and reported in the annual volumes of Jökull. Outlines of Figures 3, 4, and 5 are also shown.

to determine the exact frontal position of an outlet glacier, the error can be as much as $\pm 5 \mathrm{~m}$.

\section{Landsat sensors}

Landsat sensors have been operating since 23 July 1972, when the first multispectral scanner (MSS) and returnbeam vidicon (RBV) instruments were launched on the ERTS 1 (later renamed the Landsat 1) satellite. The MSS sensor recorded images in four spectral bands, band $4\left(0.5^{-}\right.$ $0.6 \mu \mathrm{m})$, band $5(0.6-0.7 \mu \mathrm{m})$, band $6(0.7-0.8 \mu \mathrm{m})$ and band $7(0.8-1.1 \mu \mathrm{m})$, that covered parts of the visible and nearinfrared parts of the electromagnetic spectrum at a picture element (pixel) resolution of $79 \mathrm{~m}$. An improved RBV sensor $(0.505-0.750 \mu \mathrm{m}$ panchromatic band) was flown on Landsat 3 (launched on 5 March 1978) and had a pixel resolution of $30 \mathrm{~m}$. The thematic mapper (TM) sensor was first flown, along with the MSS sensor, on the Landsat 4 satellite (launched on 16 July 1978). The TM acquires images in seven spectral bands, band $1(0.45-0.52 \mu \mathrm{m})$, band $2(0.52-0.6 \mu \mathrm{m})$, band $3(0.63-0.69 \mu \mathrm{m})$, band $4(0.76-0.9 \mu \mathrm{m})$, band $5(1.55-$ $1.75 \mu \mathrm{m})$, band $6(10.4-12.5 \mu \mathrm{m})$, and band $7(2.08-2.35 \mu \mathrm{m})$, that cover parts of the visible, near-infrared, mid-infrared and thermal infrared spectrum. TM bands $1-5$ and 7 have a pixel resolution of $30 \mathrm{~m}$; TM band 6 has a pixel resolution of $120 \mathrm{~m}$. The first three Landsat satellites $(1-3)$ had orbital repeat cycles of $18 \mathrm{~d}$; Landsats 4 and 5, however, image the same area of the Earth's surface every $16 \mathrm{~d}$, cloud cover permitting.

\section{Glacier variation from satellite measurements}

Landsat images were recognized soon after launch of the ERTS 1 spacecraft to be of value to investigations of glaciers (Williams and others, 1974; Krimmel and Meier, 1975; Østrem, 1975). In fact, Vatnajökull was, on 8 September 1972, the second Icelandic glacier to be imaged by Landsat; the first was Mýrdalsjökull on 7 September 1972. During the past 24 years, Landsat images have been used to measure glacier variations using sequential images (Williams and others, 1974; Knight and others, 1987; Lucchitta and others, 1993); to carry out preliminary glacier inventories (Williams, 1986a); and to compile a satellite image atlas of glaciers of the world (Williams and Ferrigno, 1994). Landsat images have also been used to measure spectral reflectance of glacier surfaces and to determine if such reflectivity differences can be correlated with the surface expression of glacier facies (Hall and others, 1987; Williams and others, 1991), as defined by Benson (1962) and Benson and Motyka (1979) from Benson's work on the Greenland ice sheet. Landsat images have also provided an important source of 
information for obtaining a global perspective of glaciers (Williams, 1986b; Williams and Hall, 1993).

Changes in glaciers at a number of locations throughout the world have been studied using Landsat data. Baseline information, using Landsat MSS images acquired in the mid-1970s, on glacier area and terminus position for all of the Earth's glacierized regions is in preparation as an eleven volume U.S. Geological Survey Professional Paper 1386 AK (Williams and Ferrigno, 1994); five of the eleven volumes have been published. Other work has shown that glacier recession in many areas, such as Alaska, Iceland and Austria, can be measured to an accuracy of approximately one Landsat pixel (Hall and others, 1992; Bayr and others, 1994). For example, the Pasterze glacier in the Austrian Alps receded $>90 \mathrm{~m}$ between 1984 and 1990. Some of the outlet glaciers of Vatnajökull (Fig. 2) receded $1 \mathrm{~km}$ or more between 1973 and 1992 according to Landsat images. The tidewater Muir Glacier in Glacier Bay, Alaska, receded $>7 \mathrm{~km}$ from 1973 to 1992, as measured from satellite images (Hall and others, 1995a).

Table 1. Landsat images used in the measurement of changes in the margin of Vatnajökull, 1973-92

\begin{tabular}{lcccc}
\hline \multicolumn{1}{c}{ Date } & $\begin{array}{c}\text { Image } \\
\text { type }\end{array}$ & $\begin{array}{c}\text { Solar elev- } \\
\text { ation angle }\end{array}$ & $\begin{array}{c}\text { Image identi- } \\
\text { fication .No. }\end{array}$ & Path-row \\
& & $\left(^{\circ}\right)$ & & \\
\hline 22 September 1973 & MSS & 25 & $1426-12070$ & $235-15$ \\
9 August 1978 & RBV & 38 & $30157-11565-\mathrm{C}-\mathrm{D}$ & $235-14$ \\
& & 40 & $30157-11572-\mathrm{A}-\mathrm{D}$ & $235-15$ \\
26 July 1987 & TM & 43 & $51242-11530$ & $217-15$ \\
7 September 1991 & TM & 30 & $52746-11513$ & $217-15$ \\
19 October 1992 & TM & 14 & $42170-15009$ & $217-15$ \\
& & & & \\
\hline
\end{tabular}

Landsat 3 return-beam vidicon.

Satellite images can be used to measure changes in glacier margins on a time-lapse basis, if the glacier margin can be spectrally discriminated from the terminal moraines and/or sandur (glacial outwash) deposits. In the current study, Landsat MSS, Landsat 3 RBV and TM images, spanning a 19 year period, were co-registered to measure changes in the margins of Vatnajökull. To carry out the comparative analysis between satellite-derived and groundbased measurements, only optimum Landsat images were used, with no cloud cover on one-half or more of the glacier and acquisition during the latter part of the melt season (to minimize the amount of marginal snowpack). Six Landsat images were used that fit these criteria (Table 1): one MSS (22 September 1973), two Landsat 3 RBV (9 August 1978) and three TM (26 July 1987, 7 September 1991 and 19 October 1992). The cloud-free 22 September 1973 MSS image was used as the baseline image.

\section{METHODOLOGY OF MEASURING GHANGE WITH LANDSAT IMAGES}

\section{Registration of multiple images}

In order to register Landsat images, one image is selected to be the baseline image. When images of different pixel resolution are registered, the resolution of the registered images becomes that of the image with the least pixel resolution. Thus, when the MSS and TM images were registered for the study of Vatnajökull, the pixel resolution of the resulting data is $79 \mathrm{~m}$.

To register images, first a set of "control points" is selected using image-processing software. Control points are fixed features that are common to both images, such as a shoreline of a stable lake or a rock outcrop. Greater registration accuracy is generally achieved as the number of control points is increased. In order to register the Landsat images for this project, 175 control points were located and used to register each image. A review of control points for registration of the 1973 MSS and 1987 TM images found no discernible difference; a comparison of the 1973 MSS and 1992 TM images, however, found a one-pixel misalignment of registration on the northeastern margin of Vatnajökull that affected satellite-derived measurements of Brúarjökull and Eyjabakkajökull. Therefore, the 1973-92 measurement error for these two outlet glaciers is $\pm 191 \mathrm{~m}$ instead of $112 \mathrm{~m}$ (see "Measurement of changes between image dates" in next section). Also, depending on the type of printer used, the image geometry of computer-generated prints may be distorted.

\section{Delineation of the glacier margin}

Satellite images of a glacier permit the entire margin to be analyzed for changes, not just the 23 fixed survey stations for Vatnajökull from which marginal fluctuations are generally monitored and measured annually (see arrows in Figure 2). Once two different images are registered, one can delineate the changes in margins of ice caps and the termini of outlet glaciers. Delineating the exact position of an ice-cap margin or terminus of an outlet glacier can be straightforward, if there is a sharp spectral difference between glacier ice and the surrounding terrain. On the computer monitor, a mouse-driven cursor is used to digitize a line that traces the margin of the ice cap; the glaciologist, preferably one with "local knowledge", must decide where the precise margin is. Situations in which ambiguity exists as to where the margin is will be discussed in the next section. Various color lines can be used to outline the changing positions of the margins of ice caps and outlet glaciers. Glacier margins imaged in different years can then be compared (Fig. 3). One can also "flicker" the registered images on the computer monitor to observe changes.

\section{ANALYSIS}

\section{Problems associated with delineating margins}

Complicating factors in the delineation of the margin of Vatnajökull included the following: (1) lack of the third dimension in the Landsat images, (2) spectral similarities of supraglacial morainic debris and the terminal moraine and/or sandur (not usually a problem with an advancing outlet glacier, often a problem with a receding and downwasting margin), (3) marginal snowpack, and (4) changes in spectral reflectivity caused by low solar elevation angle of illumination of the scene. To some degree, the delineation problem can be reduced by image enhancement, the presence of ice-margin (proglacial) lakes, location of the origin of glaciofluvial outwash channels and use of images that have solar-elevation angles of $\geq 25^{\circ}$. 

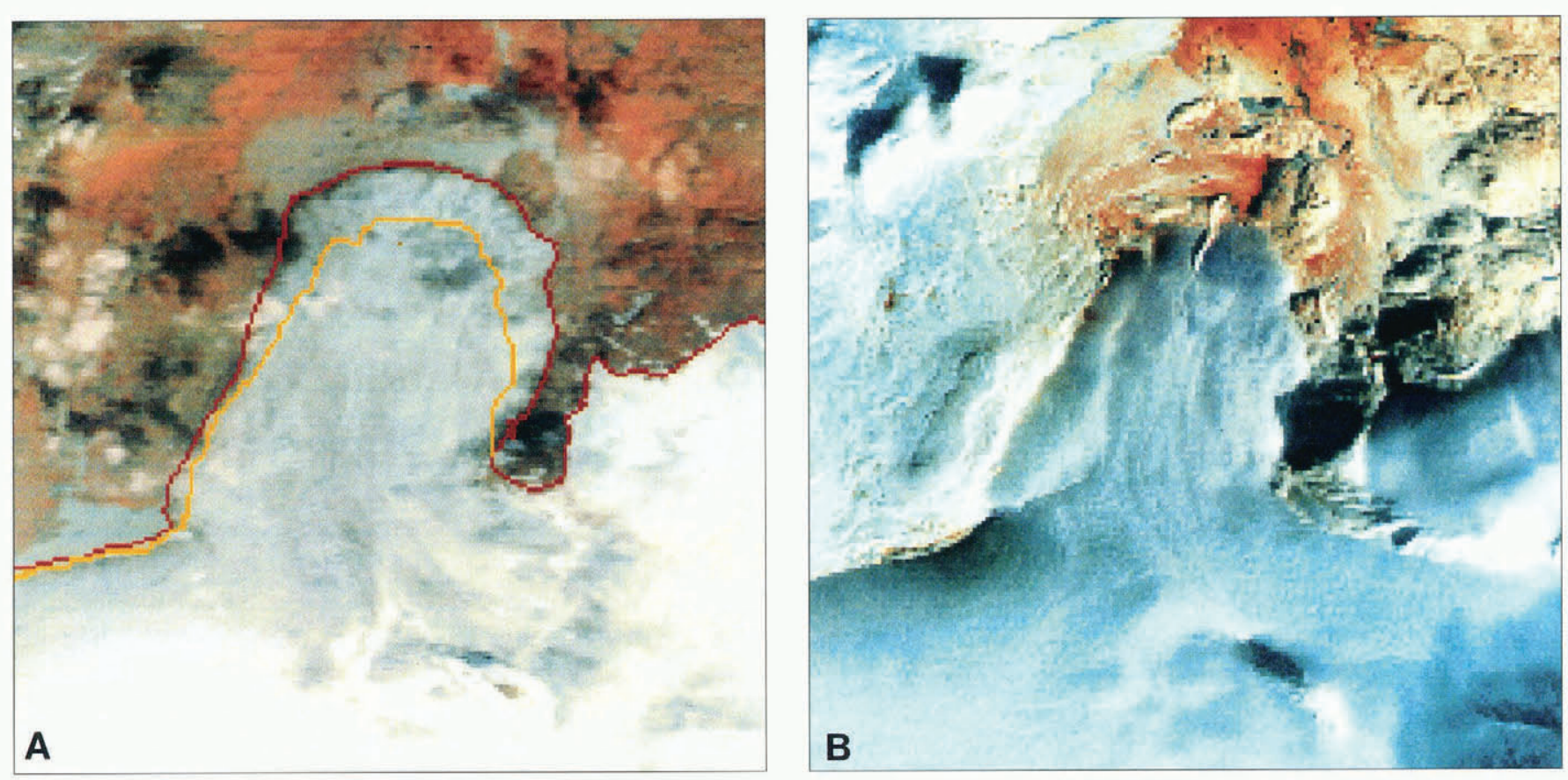

Fig. 3. Delineation of the margin of the Eyjabakkajökull outlet glacier, a surging glacier on the northeast margin of Vatnajökull. Eyjabakkajökull last surged about 1.5-2 km in 1972-73 and has been stagnant since then. The red line delineates the terminus on 22 September 1973 as it was nearly completed with the surge. The yellow line delineates the terminus on 19 October 1992, after 19 years of melting of the stagnant lower part of the outlet glacier, a recession of $921 \pm 191 \mathrm{~m}$. On the 22 September 1973 image (a), that was used as the base image, an ephemeral ice-margin lake is visible on the left where the outlet glacier emerges from the ice cap; it is not visible on the 19 October 1992 image (b). An ice-margin lake is also visible at the terminus. The margin of Eyjabakkajökull is easily delineated after it advanced in 1973; it is more difficult to delineate on the 1992 image. (See Fig. 2 for location.)

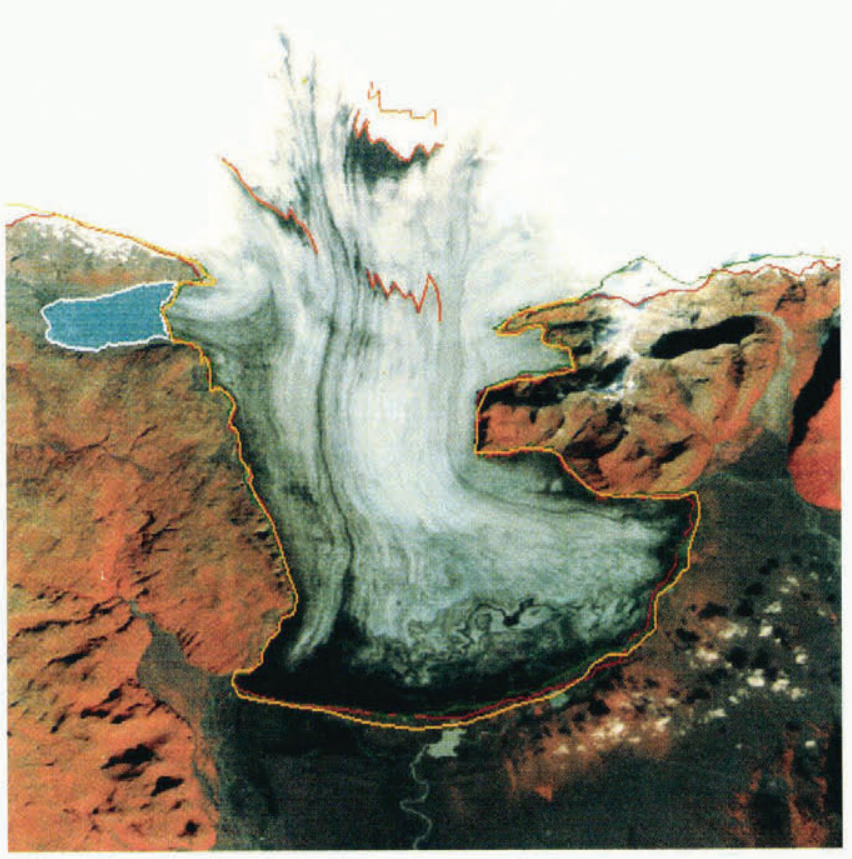

Fig. 4. Delineation of terminus of the Skeidarárjökull outlet glacier and margin of Vatnajökull from the 22 September 1973 Landsat image (red). The margin of the outlet glacier is plotted for three different years 1973 (red), 1987 (green) and 1992 (yellow). Ice-margin lakes are visible on the sandur. A distributary glacier on the left dams Grenalón, an ice-margin lake that drains annually as a jökulhlaup along the western margin of Skeidarárjökull before debouching onto Skeiðarársandur to the south. Skeidarárjökull began a surge in 1991. Deformed tephra layers within the glacier are visible on the surface east of Graenalón (delineated in red on the 1973 image; see Fig. 2 for location).

\section{Lack of a third dimension}

Except in image-overlap areas of orbitally adjacent images, satellite images provide only a two-dimensional view of glaciers and the surrounding terrain, so that spectral differentiation becomes the key to accurately delineating the glacier margin. Stereoscopic images would help delineate the margin where there is a marked topographic difference between the glacier, terminal moraine and surrounding terrain.

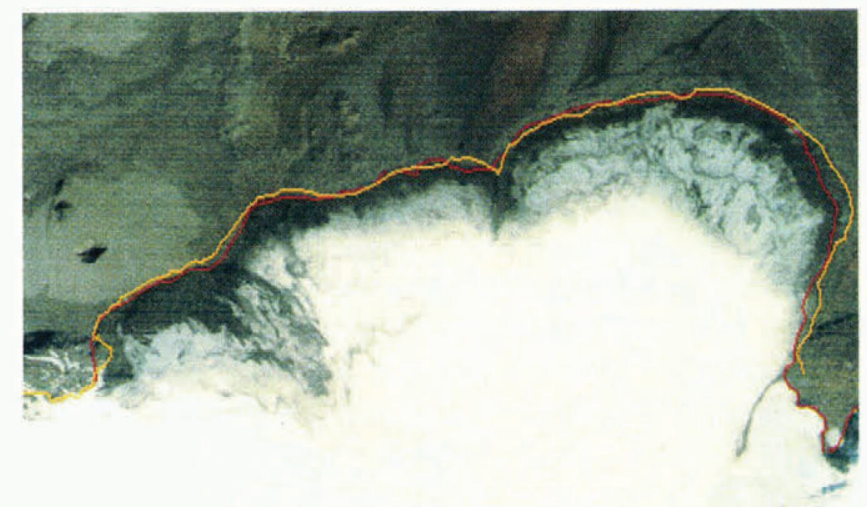

Fig. 5. Delineation of the margin of Dyngjujökull, a broad outlet glacier on the northwestern margin of Vatnajökull, in 1973 (red) and 1992 (yellow). The easternmost part of the lobe advanced $+553 \pm 112 \mathrm{~m}$. There are no ground-observation stations along the entire margin of Dyngjujökull, so infrequent vertical aerial photography and satellite images represent the best means of periodically monitoring changes in its lengthy terminus. (See Fig. 2 for location.) 


\section{Spectral similarity}

When a glacier front has been stationary, receding or downwasting, the entrained rock debris that is being carried by the glacier will appear on the glacier surface as the ice melts. This debris has the same spectral signature as the surrounding bedrock and surrounding glacial landforms, such as sandur and moraines. Under such conditions of spectral similarity, it is difficult to locate the position of the terminus of a receding glacier (Hall and others, 1992). Therefore, one must use other evidence to be able to delineate the terminus. In Figures 3 and 4, ice-margin lakes are visible that define where the debris-covered glacier margin is located. Icemargin lakes form at favorable locations along ice-cap and outlet glacier margins, wherever meltwater is impounded by the glacier on one side, sloping terrain exists in front of the glacier and a morainic dam is present. In some cases, tributary valleys are dammed by an outlet glacier forming a distributary, such as the small western lobe of Skeidarárjökull, and may cause a lake to form (e.g. Grænalón; Figs 2 and 4). Most such lakes change their shape seasonally, and some may be the source of periodic rapid-drainage events (jökulhlaups), such as Grænalón (Fig. 4). Advancing glaciers often have "clean" termini that are markedly dissimilar spectrally from the surrounding morainic and outwash deposits. Glacier termini that end in a lake or the ocean also have a large spectral dissimilarity between ice and water (Fig. 4). Under such circumstances the delineation of the glacier margin is simple.

\section{Marginal snowpack}

Snowpack can also cause problems in accurately delineating the margin of a glacier, by either masking terminal or lateral moraines or being difficult to differentiate from glacier ice. Under such conditions, it is easy to produce a false measurement of the glacier margin and glacier area. The best time of year to measure glacier change is at the end of the melt season, after the previous year's snowpack has melted or reduced to a minimum. The time of minimum snow cover provides the opportunity to achieve good spectral contrast between the glacier margin and the surrounding terrain.

\section{Low solar elevation angle of illumination of scene}

The 19 October 1992 TM image, with a solar elevation angle of $14^{\circ}$, initially caused problems in accurately delineating the margin of outlet glaciers in southwestern Vatnajökull; the area of downwasting and recession of Tungnaárjökull between 1973 and 1992 was misidentified, causing the margin to be delineated in the wrong location. A re-examination and reanalysis of the 1973-92 image pairs produced an accurate position of the margin.

\section{Time-lapse interval}

It is ideal if satellite data can be acquired at regular intervals, so that one can measure the changes in a glacier. If the interval between images is too short, there may not be measurable changes. On the other hand, if the time interval is too long, interim changes may be missed; therefore, the observed changes may be misinterpreted. Eyjabakkajökull (Fig. 3) surged about $0.5-1 \mathrm{~km}$ in 1972 and an additional $1 \mathrm{~km}$ in 1973, after being in a quiescent state since its last surge in 1938. Considerable recession had occurred between
1973 and 1992 (Fig. 3), so images taken prior to the 1972-73 surge that are compared with 1992 images would "miss" some of the $1.5-2 \mathrm{~km}$ advance.

\section{Measurement of changes between image dates}

Co-registration of sequential Landsat images and delineation of the terminus of an outlet glacier on the co-registered images permitted measurements to be made of the amount of advance or recession between two or more dates with an accuracy of $\pm 112 \mathrm{~m}$ for MSS images and for comparison with changes delineated on Landsat $3 \mathrm{RBV}$ and TM data. The accuracy of Landsat $3 \mathrm{RBV}$ and TM or TM and TM data is $\pm 42 \mathrm{~m}$.

The $\pm 112 \mathrm{~m}$ (and $\pm 42 \mathrm{~m}$ ) error is calculated as follows. A single measurement of glacier margin position will fall within or at the edge of a single $79 \mathrm{~m}$ pixel, on MSS $(30 \mathrm{~m}$ pixel on Landsat $3 \mathrm{RBV}$ and TM images) giving a range of $\pm 79 \mathrm{~m}$ for the width of a pixel to either side $( \pm 30 \mathrm{~m}$ for RBV and TM data). The second measurement of glacier margin will be the same error. The error of a series of measurements of similar quantities is $E \sqrt{n}$, where $E$ is the error of measurement $(79 \mathrm{~m})$ and $n$ is the number of measurements in the series (2). Therefore, the error is $79 \mathrm{~m} \times 6 \sqrt{2}=$ $\pm 112 \mathrm{~m}$ (or $\pm 42 \mathrm{~m}$ for RBV and TM data).

Using PCI EASI/PACE ${ }^{\mathrm{TM}}$ software on a Silicon Graphics $^{\mathrm{TM}}$ workstation, the number of pixels can be counted between the two positions of the margin or terminus and multiplied by the size of the pixel $79 \mathrm{~m}$ in the case of superimposed images, one being an MSS image) to calculate the distance that the outlet margin or outlet glacier terminus has receded or advanced between the two dates. Table 2 summarizes these calculations for 1973-87, 1973-78, 197391, 1973-92, and 1987-92 registered image pairs. Most of the measurements of glacier fluctuation were done with the 1973-87 and 1973- 92 image pairs.

\section{RESULTS}

\section{Changes in position of outlet glaciers}

Changes of the margins of many of the outlet glaciers of Vatnajökull were measured using Landsat MSS and TM data from 1973-92. While most of the margins of the ice cap receded, some margins advanced and others were stable. The largest changes during the 19 year period occurred in the large lobate outlet glaciers along the southwestern, western and northern margins of Vatnajökull. Beginning at the southwestern margin of Vatnajökull at the Tungnaárjökull outlet glacier and proceeding in a counter-clockwise direction, we will summarize the changes measured using Landsat data and compare these measurements with ground-based observations (Table 2).

\section{Comparison of satellite-derived and ground-based fluctuations}

Table 2 summarizes satellite-derived fluctuation measurements on 11 of Vatnajökull's 38 named outlet glaciers (Fig. 2) and compares six of them with ground-based observations. Two outlet glaciers, Fláajökull and Kverkjökull, were measured on 1973 Landsat MSS and 1987 and 1991 Landsat TM images (Table 1), but the changes were smaller than the pixel resolution of the MSS image. Two outlet glaciers from the Öræfajökull interior ice cap, Skaftafellsjökull and Svína- 
Table 2. Comparison of satellite-derived and ground-based measurements of the termini of some of the outlet glaciers of Vatnajökull (fluctuations in meters)

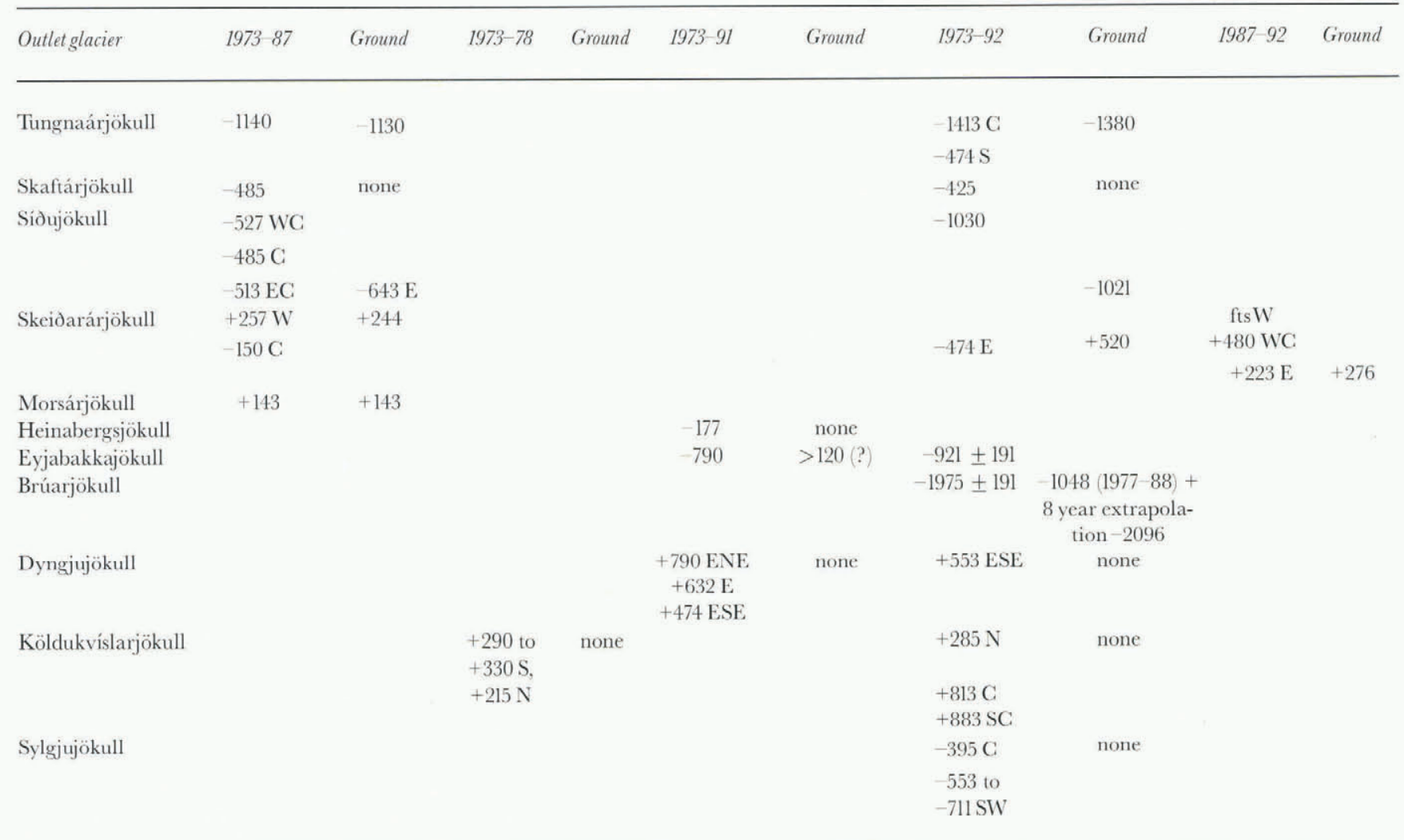

W, west; C, center; E, east; NE, northeast; SE, southeast; SW, southwest; see Table 1 for information on Landsat image dates. fts, fluctuation too small to measure on Landsat images. Ground fluctuations for the same span of dates, where available, given in the column to the right following satellite calculations. Comparison of ground measurements with satellite-derived measurements for Eyjabakkajökull is uncertain, because a conventional cairn-to-terminus distance was not used. Also, the development of a proglacial lake at the terminus of Heinabergsjöull has precluded ground measurements since 1973. The error in satellite-derived measurements is $\pm 112 \mathrm{~m}$ except for Brúarjökull and Eyjabakkajökull in $1973-92$ ( $\pm 191 \mathrm{~m}$ ) because of a one pixel misregistration of 1973 and 1992 images in northeastern Vatnajokull. Ground-based measurements have an error of $\pm 1 \mathrm{~m}$, except for $\pm 5 \mathrm{~m}$ when determination of the exact position of the terminus of an outlet glacier is questionable.

fellsjökull, were measured on the 1973 MSS and 1987 TM images, but the fluctuation was also too small to be resolved by the $79 \mathrm{~m}$ pixel resolution of the MSS image. Total ground-based measurements of fluctuation for the period 1973-87 were $+110 \pm 1 \mathrm{~m}$ for Skaftafellsjökull and $+11 \pm 1 \mathrm{~m}$ for Svínafellsjökull, each too small a variation to be discerned on the MSS image.

Five outlet glaciers of Vatnajökull on its southwestern, southeastern, northwestern and western margins do not have systematic observations from established groundbased stations. In a counter-clockwise direction, they are: Skaftárjökull, Heinabergsjökull, Dyngjujökull, Köldukvíslarjökull and Sylgjujökull. Consequently, only the satellite-derived measurements of fluctuations for these five outlet glaciers are given in Table 2 .

Three lobate outlet glaciers in southwestern Vatnajökull (Tungnaárjökull, Skaftárjökull and Siðujökull; Fig. 2) surged in 1994; they had all been in recession before 1973 and during the period 1973-92. Tungnaárjökull had the greatest recession of all of the lobate outlet glaciers in southwestern Vatnajökull. On 1973 MSS and 1987 TM images, it receded $-1140 \pm 112 \mathrm{~m}$; ground-based observations during the same period showed a recession of $-1130 \pm 1 \mathrm{~m}$. On 1973 MSS and 1992 TM images, it receded $-1413 \pm 112 \mathrm{~m}$ in the center near the ground-observation station, but only $-474 \pm 112 \mathrm{~m}$ on the southern margin of the lobe. Ground measurements during the same period were $-1380 \pm 1 \mathrm{~m}$.
Skaftárjökull had receded $-485 \pm 112 \mathrm{~m}$ on 1973 MSS and 1987 TM images and $-425 \pm 112 \mathrm{~m}$ on 1973 MSS and 1992 TM images; there is no ground-based observation station to corroborate these measurements.

On 1973 MSS and 1987 TM images, Siðujökull had receded $-527 \pm 112 \mathrm{~m}$ in its west-central part, $-485 \pm 112 \mathrm{~m}$ in its central part, and $-513 \pm 112 \mathrm{~m}$ in its east-central part. During the same period of time, ground observations showed a recession of $-643 \pm 1 \mathrm{~m}$ on its eastern part. On 1973 MSS and 1992 TM images, Siðujökull had receded $-1030 \pm 112 \mathrm{~m}$; ground observations showed a recession of $-1021 \pm 1 \mathrm{~m}$ for the same period. Sidujökull last surged in $1963-64$ at least $0.5 \mathrm{~km}$, although field evidence suggests that the total surge was probably much more.

Skeiðarárjökull (Fig. 4), on the basis of 1973 MSS and 1987 TM images, had advanced $+257 \pm 112 \mathrm{~m}$ on its western lobe and had receded $-150 \pm 112 \mathrm{~m}$ in its central part. Comparable ground observations of the western lobe during the 1973-87 period showed an advance of $+244 \pm 1 \mathrm{~m}$. Skeidarárjökull began a surge in 1991, so the Landsat images that postdate 1991 will show an advance. In the eastern part of its margin, 1973 MSS and 1992 TM images show an advance of $+474 \pm 112 \mathrm{~m}$; comparable ground observations showed an advance of $+520 \pm 1 \mathrm{~m} .1987 \mathrm{TM}$ and $1992 \mathrm{TM}$ images show an advance of its terminus of $+480 \pm 42 \mathrm{~m}$ in the westcentral part and $+223 \pm 42 \mathrm{~m}$ in the eastern part. Comparable ground observations for this latter period showed an 
advance of $+276 \pm 1 \mathrm{~m}$. Changes in the western part of the lobe on 1987 and 1992 TM images were too small to measure on the Landsat images.

The post-surge (surge in 1972-73, for a total advance of $1.5-2 \mathrm{~km}$ determined from ground observations) recession of Eyjabakkajökull has been $-790 \pm 191 \mathrm{~m}$ on 1973 MSS and 1991 TM images, $-921 \pm 191 \mathrm{~m}$ on 1973 MSS and 1992 TM images (Fig. 3). There have been no ground measurements of the terminus of Eyjabakkajökull since 1985. On the 1973 MSS image its terminus was $2095 \pm 79$ m wide; on the 1992 TM image it was $1387 \pm 30 \mathrm{~m}$ wide, reflecting the rapid downwasting and recession of the stagnant terminus following the 1972-73 surge.

Following a surge in 1963-64 of $+8 \mathrm{~km}$, Brúarjökull has been actively receding. Ground observations for the period 1977-88 show that its broad terminus had receded $-1048 \pm 5 \mathrm{~m}$. No ground observations were made during the 1972-77 and 1988-92 periods, although a linear extrapolation of downwasting and recession would give $2096 \pm 5 \mathrm{~m}$ for the period 1972-92. Although Brúarjökull presents a difficult problem in delineating the glacier ice and terminal moraine contact, because of massive downwasting all along its stagnant terminus, measurements were made on 1973 MSS and 1992 TM images. The terminus had, during this period of time, receded $-1975 \pm 191 \mathrm{~m}$ at the approximate position of the ground-observation station.

On 1973 MSS and 1991 TM images, Dyngjujökull's margin had advanced $+790 \pm 112 \mathrm{~m}$ on the east-northeastern, $+632 \pm 112 \mathrm{~m}$ on the eastern, and $+474 \pm 112 \mathrm{~m}$ on the east-southeastern parts of its eastern margin; on the 1973 MSS and 1992 TM images its east-southeastern margin advanced $+553 \pm 112 \mathrm{~m}$ (Fig. 5). On Köldukvíslarjökull, on 1973 MSS and 1978 RBV images, it had advanced from $+290 \pm 112 \mathrm{~m}$ to $+330 \pm 112 \mathrm{~m}$ on its southern margin and $+215 \pm 112 \mathrm{~m}$ on its northern margin; on 1973 MSS and 1992 TM images its western margin had advanced between $+285 \pm 112 \mathrm{~m}$ on the north and $+883 \pm 112 \mathrm{~m}$ on the southcentral part of the lobe. On 1973 MSS and 1992 TM images, Sylgjujökull receded $-395 \pm 112 \mathrm{~m}$ in the center of the lobe to between $-553 \pm 112 \mathrm{~m}$ and $-711 \pm 112 \mathrm{~m}$ on its southwestern lobe.

\section{CONGLUSIONS}

In the specific case of Iceland, Landsat images permit the monitoring of fluctuations along most of Vatnajökull's margin, not just at the 23 ground-observation stations (19 individual outlet glaciers) monitored on an annual basis at an accuracy of about $112 \mathrm{~m}$ with MSS images and $42 \mathrm{~m}$ for Landsat $3 \mathrm{RBV}$ or TM images. Within the margins of error, we found good correspondence between the satellite-derived and ground-based measurements of six outlet glaciers of Vatnajökull during the period 1973-92. One aspect of our comparison of measurements of glacier fluctuations made from Landsat images vs ground-based observations is the critical importance of having "local knowledge" of glaciers to support the analysis of Landsat images.

Based on these results, we have confidence in the accuracy of the measurement of fluctuation of five additional outlet glaciers for which ground observations are not available. For four other outlet glaciers for which groundobservation stations exist, the ground-based measurements were $\leq 110 \pm 1 \mathrm{~m}$; no fluctuation could be discerned with satellite-derived measurements of these four outlet glaciers.

For the larger glaciers, such as ice fields, ice caps and ice sheets, the capability now exists to begin to build an archive of long-term data sets of the fluctuations of large glacier margins and area on a global basis, using glaciological data based on analysis of current satellite sensor data. If the World Glacier Monitoring Service expands its area of interest from small glaciers to the larger glaciers (e.g. ice fields, ice caps, ice sheets and the outlet glaciers that comprise each), satellite images will be an important source of data for monitoring and measuring changes in glacier margins on a regional (and global) basis, in association with glaciologists who have "local knowledge" of glaciers of their specific region, and in the building of an international archive of long-term data sets. Improvements in the pixel resolution of imaging sensors, use of radar imagers, the annual acquisition of satellite images and acquisition of geodetically accurate laser altimetry from Earth-orbiting satellites will eventually provide considerably more data of value to glaciologists who are monitoring and measuring changes in glacier margins, area and volume (Williams and Hall, in press).

\section{REFERENCES}

Ahlmann, H.W:son and S. Thórarinsson, eds. 1937 -43. Vatnajökull: scientific results of the Swedish Icelandic investigations 1936-37-38. Geogr. Ann. $19(3-4), 1937,146-231 ; 20(3-4), 1938,171-233 ; 21(1), 1939,39-66 ; 21(3-4)$, 1939, 171-242; 22(3-4), 1940, 188-205; $25(1-2), 1943,1-54$.

Bayr, K. J., D. K. Hall and W. M. Kovalick. 1994. Observations on glaciers in the eastern Austrian Alps using satellite data. Int. 7. Remote Sensing, $15(9), 1733-1742$.

Benson, C. S. 1962. Stratigraphic studies in the snow and firn of the Greenland ice sheet. SIPRE Res. Rep. 70.

Benson, C. S. and R. J. Motyka. 1979. Glacier-volcano interactions on Mt. Wrangell, Alaska. University of Alaska, Fairbanks. Geophysical Institute. Annual Report, 1977-78, 1-25.

Björnsson, H. 1980a. The surface area of glaciers in Iceland. Jökull, 28, 1978 , $31-32$.

Björnsson, H. 1980b. Glaciers in Iceland. Jökull, 29, 1979, 7480.

Björnsson, H. 1988. Hydrology of ice caps in volcanic regions. Visindafélag Isl. Rit 45.

Eiríksson, H. H. 1932. Observations and measurements of some glaciers in Austur-Skaftafellssýsla. Visindafêlag Isl. Rit 12.

Eypórsson, J. 1931. On the present position of the glaciers in Iceland: some preliminary studies and investigations in the summer 1930. Visindafèlag Isl. Rit 10.

Eypórsson, J. 1949. Variations of glaciers in Iceland, 1930 -47. J. Glaciol., 1 (5), $250-252$.

Eypórsson, J. 1963. Variation of Icelandic glaciers 1931-1960. Jökull, 13,31 33.

Garvin, J. B. and R. S. Williams, Jr. 1993. Geodetic airborne laser altimetry of Breidamerkurjökull and Skeidarárjökull, Iceland, and Jakobshavns Isbra, West Greenland. Ann. Glaciol., 17, 379385.

Hacberli, W. 1995. Glacier fluctuations and climate change detection operational elements of a worldwide monitoring strategy. WMO Bull., $44(1), 23-31$.

Haeberli, W. and M. Hoelzle. 1995. Application of inventory data for estimating characteristics of and regional climate-change effects on mountain glaciers: a pilot study with the European Alps. Ann. Glaciol., 21, 206-212.

Hall, D. K., J. P. Ormsby, R. A. Bindschadler and H. Siddalingaiah. 1987. Characterization of snow and ice reflectance zones on glaciers using Landsat thematic mapper data. Ann. Glaciol., 9, 104-108.

Hall, D. K., R. S. Williams, Jr and K. J. Bayr. 1992. Glacier recession in Iceland and Austria as observed from space. EOS, 73(12), 129, 135, 141.

Hall, D. K., C. S. Benson and W. O. Field. 1995a. Changes of glaciers in Glacier Bay, Alaska, using ground and satellite measurements. Phys. Geogr., 16 (1), 27-41.

Hall, D.K., R.S. Williams, Jr and O. Sigurdsson. 1995b. Glaciological observations of Brúarjökull, Iceland, using synthetic aperture radar and 
thematic mapper satellite data. Ann. Glaciol., 21, 271-276.

Knight, P., R. Weaver and D. Sugden. 1987. Using Landsat MSS data for measuring ice sheet retreat. Int. 7. Remote Sensing, 8 7), 1069-1074.

Krimmel, R. M. and M. F. Meier. 1975. Glacier applications of ERTS images. 7. Glaciol., 15 (73), 391-402.

Lucchitta, B. K., K. F. Mullins, A. L. Allison and J. G. Ferrigno. 1993. Antarctic glacier-tongue velocities from Landsat images: first results. Ann. Glaciol., 17, 356-366.

Meier, M. F. 1984. Contribution of small glaciers to global sea level. Science, 226 (4681), 1418-1421.

Oerlemans, J. 1994. Quantifying global warming from the retreat of glaciers. Science, 264(5156), 243-245.

Ostrem, G. 1975. ERTS data in glaciology - an effort to monitor glacier mass balance from satellite imagery. 7. Glaciol., 15 (73), 403-415.

Paterson, W. S. B. 1994. The physics of glaciers. Third edition. Oxford, etc., Elsevier.

Sigurdsson, O. and T. Jónsson. 1995. Relation of glacier variations to climate changes in Iceland. Ann. Glaciol., 21, 263-270.

Thórarinsson, S. 1960. Glaciological knowledge in Iceland before 1800: a historical outline. Jökull, 10,1-18.

Thórarinsson, S. 1969. Glacier surges in Iceland with special reference to the surges of Bruarjökull. Can. 7. Earth Sci., 6 4), Part 2, 875882.

Thórarinsson, S. 1974. Vötnin strid saga Skeidarárhlaupa og Grimsvatnagosa Fastflowing rivers: the history of jökulhlaups in Skeidará and eruptions in Grimsvötn . Reykjavik, Bókaútgáfá Menningarsjóds.

Thórarinsson, S., K. Sæmundsson and R. S. Williams, Jr. 1974. ERTS-1 image of Vatnajökull: analysis of glaciological, structural, and volcanic features. Jökull, 23, 1973, 7-17.
Thoroddsen, T. 1892. Islands Jokler i fortid og nutid. Geogr. Tidsskr., 11 (5-6), $111-146$.

Williams, R. S., Jr. 1983. Satellite glaciology of Iceland. Jökull, 33, 3-12.

Williams, R. S., Jr. 1986a. Glacier inventories of Iceland: evaluation and use of sources of data. Ann. Glaciol., 8, 184-191.

Williams, R. S., Jr. 1986b. Glaciers and glacial landforms. In Short, N. M. and R. W. Blair, Jr, eds. Geomorphology from space: a global overview of regional landforms. Greenbelt, MD, National Aeronautics and Space Administration. Goddard Space Flight Center, 521-596. (NASA SP-486.)

Williams, R. S., Jr. 1987. Satellite remote sensing of Vatnajökull, Iceland. Ann. Glaciol., 9, 127-135.

Williams, R. S., Jr and J. G. Ferrigno. 1994. Satellite image atlas of glaciers of the world. U.S. Geol. Surv. Global Change Fact Sheet FS-94-009.

Williams, R. S., Jr and D. K. Hall. 1993. Glaciers. In Gurney, R. J., J. L. Foster and C. L. Parkinson, eds. Atlas of satellite observations related to global change. Cambridge, Cambridge University Press, 401-422.

Williams, R.S., Jr and D. K. Hall. In press. Use of remote sensing techniques, In Haeberli, W., ed. Into the 2 nd century of world glacier monitoring: prospects and strategies. Paris, UNESCO International Hydrological Programme. (IHP Series.)

Williams, R. S., Jr and 8 others. 1974. Environmental studies of Iceland with ERTS-1 imagery. Proceedings of the Ninth International Symposium on Remote Sensing of the Environment, 15-19 April 1974.Vol. 1. Ann Arbor, MI, Environmental Research Institute of Michigan, 31-81.

Williams, R. S., Jr, D. K. Hall and C. S. Benson. 1991. Analysis of glacier facies using satellite techniques. f. Glaciol., 37 (125), 120-128.

Wood, F. B. 1988. Global alpine glacier trends, 1960s to 1980s. Arct. Alp. Res., $20(4), 404-413$. 